\title{
ENTREPRENUERSHIP PRACTICES IN CONTEMPORARY NIGERIA: CHALLENGES AND A WAY FORWARD TOWARDS BUILDING A STRONG NATION
}

\author{
Danladi Bala \\ Department of Business Administration \\ Nnamdi Azikwe University, Awka \\ danladibala2077@gmail.com \\ 08038317070 \\ Ali Ahmadu Gawuna \\ Department of Marketing \\ School of Management Studies, \\ Kano State Polytechnic \\ kanojosima@gmail.com \\ 08068136133
}

\begin{abstract}
The aim of this research is to determine the entrepreneurs' perception on the quality of their operation in Nigerian business environment in relation to building strong nation. It is no longer secret that most Nigerian goods cannot compete in terms of price and quality in the open international market. The problem lies in the cost profile of our manufacturing processes, inefficient design of entrepreneurship business, poor management of entrepreneurs funds which hardly been helped by the high cost of obtaining basic service that are taken for granted elsewhere. Effective implementation of policy is the best way out of these problems. The methodology adopted was conceptual in nature, intensive library work was carried out to explicate the theoretical issues, also the study relied heavily on Secondary data which is collected and published by CBN, SMEDAN, Text book, Journals, Periodicals and other related documents. The finding from the previous researchers revealed a positive relationship between entrepreneurship practices and nation building. Therefore, the study recommends appropriate authority should create a viable programme with aim of improving and enriching the effectiveness of those programmes as well as providing the necessary update to keep track of the pace of building strong Nation. And for Nigeria business environment to be salvaged from being the shadow of its former self, business policies must be backed up with appropriate funding, with commitment, Sincerity and consciousness of direction for greater good for all entrepreneur toward building a strong nation.
\end{abstract}

Keywords: Entrepreneurs, Price, Quality Service, Policy Effectiveness, Strong Nation. 


\section{Introduction}

Entrepreneurship makeup the largest proportion of businesses all over the world and are hence the engine that drives world financial system and the stepping stone to industrial development, both for developing and developed Nations. According to Chea (2009), small scale enterprises account for about $88 \%$ while $12 \%$ is credited to the medium industries in Malaysia. In Nigeria, SMEs make up about $97 \%$ of the economy, they play a very vital role in the development of the economy through job creation, poverty alleviation and foreign exchange conservation (Imeokparia and Ediagbonya, 2014). The general concern about the concept of entrepreneur by the owners, beneficiaries, stakeholders and researchers from within or outside the discipline has yielded in to a serious situation in which different perceptions from different scholars have viewed the concept. In addition, the paper is of the view that in a country of an estimated over 170 million people, where government cannot provide adequate and secured jobs to the teaming/unemployed youth, The need of an entrepreneurship and innovation programme has become the bedrock of the Nigeria society to develop in order to meet up with the challenges facing the economic state of the nation.

Small and Medium enterprises will have the capacity to absorb many people in the society and capture qualified innovator and entrepreneurs that will propel economic growth and prosperity of the nation. Entrepreneurs are those people who are trying to initiate a business action, taking in to consideration the calculated risk involved. They are deterred because they are aware of the close relationship between risk and reward. The ability to make life better depends on every individual, it is therefore important to think independently. Other people can only assist facilitating entrepreneurial business. The facilitation could be done through:

$=$ Empowering people to be able to solve their own problems in a sustainable short term solution.

$=$ Giving aids which is temporary fix.

Businesses are in all size; Small, Medium or Large. The beginner may develop the ideas at any level.

However, from the above background, there is need to determine who is entrepreneurs, assess how to managed one man business, partnership, joint ventures in Nigerian business environment. The following objectives will pursuit to effectively conduct this study.

i To ascertain the relationship between entrepreneurship practices and nation building.

ii To identify the challenges that entrepreneurs encountered during their operation.

iii To identify the areas of deficiency in design of entrepreneurship business.

iv To identify the way forward in managing effective entrepreneurship 


\section{Literature Review}

Entrepreneurship can be seen as an aspect that embraces much more than buying and selling of goods. This assertion may be based on the fact that entrepreneurs have been trapped in to engaging their activities in continuous process or normal sequence. This study is based on several theoretical views; these theories form the basis upon which the research is anchored. Entrepreneurship like other disciplines, is guided by theories, these theories determined the factors that influence the emergence behaviour and performance of entrepreneurs both in the developed and less developed world. The behaviour of an entrepreneur is largely influenced by some fundamental factors which lead to its success; these factors range from social relations, political factors, innovation, structure of organization, training and development, the environment, previous working experience etc. All the above mentioned factors contribute to influence the emergence and performance of entrepreneurs and they are anchored on theories of entrepreneurship.

Weber (1930) in his theoretical studies and formulation views that religious ideas can stimulate economic development, which leads to the development of the entrepreneurial spirit. Although this view is sociological in nature, he maintained that certain teachings and attitudes prevalent in the society were crucial prescription for economic growth. Weber used the protestant ethics in his days to support his claims and these were substantiated with practical examples taken from two maxian villages. An investigation was conducted to find out the changes that occurred as a result of the introduction of a new church (protestant) in one of the villages. It was apparently discovered that the settlement of a protestant reformation in that village brought a lot of changes and development such as the establishment of missions, schools and clinics through which the villages became more enlightened. Children became more ambitious and parent more enlightened, and they demonstrated this by taking their illness to clinic, their children to school, their savings to the bank, forsaking witchcraft, drinking and marrying many wives. According to Weber, entrepreneurship development arises only within a social group, which holds values similar to the protestant ethic as seen above.

Kilby (1968) postulated that entrepreneurs in developing economies should be concerned with adoption of production processes, through which they can be familiar with their environmental setting and by constant monitoring and evaluation, that can get their business objectives achieved. Maclelland (1961) in his own contribution, argued that entrepreneurial behaviour in business is motivated by the individual need for achievement. Although his position is psychological, which he demonstrated by using Maslow hierarchy of needs referred to as "n'" achievement. Casson (1945) views entrepreneur as someone who has different skills for Co-ordination of the available scarce resources. He criticized the neoclassical and orthodox economics theory for being static and being unable to make a satisfactory account of the economic function of the entrepreneurs because 'all the functions performed by one person have already performed by someone else. He also rejected the position of the Austrian school of economics, because the extreme subjective makes a predictive theory of the entrepreneurs impossible. Casson (1982) define entrepreneur as " someone who specializes in making judgmental decisions about the coordination of scarce resources" The entrepreneur therefore requires having resources to support his judgment and 
is expected to have personal wealth because lack of capital will be a barrier to successful entrepreneur's activity.

\section{Conceptual exploration of entrepreneurship}

Entrepreneurship remains an important sub-sector in a nation's economy. The contribution of entrepreneurship has been recognized as critical to the development of an economy as they possess great potentials for poverty alleviation, employment generation, improvement of local technology, output diversification, development of indigenous entrepreneurship and forward integration with large scale industries (CBN, 2018). Entrepreneurship like any other disciplines has no Universal definition. This is because many scholars have viewed it in different ways. However, for the purpose of this research the following definitions will be captured and adopted. Stevenson and Gumpert (1985) defined entrepreneurship as the process of creating value by pulling together a unique package of resource to exploit an opportunity. Ronstadt (1984) on his part, sees entrepreneurship as "the dynamic process of creating incremental wealth," he stated that wealth is created by individual who assume the major risk in terms of equity, time and or career commitment or provide values for some products and services, which may or not be new or unique. However, that value must somehow be infused by the entrepreneurs through receiving and allocating the necessary skill and resources.

Conversely, Jones and Sakong (1980) see entrepreneurship as "force that mobilizes other resources to unmet market demand." Gartner (1989), low and Macmillan (1988) view entrepreneurship as the creation of new enterprises. However, By-grave and Hoffer (1991) define entrepreneurship According to the purpose and goals. He further says it is a process of creating a new organization and pursuing it, According to them, the process of entrepreneurship involves all functions, activities and actions associated with the perceiving of opportunities and the creation of organization to pursue them. On the other hand, Abraham (1999) sees entrepreneurship as a process that has to do with the concept, approach to doing new things within a new philosophy of value, purpose, utility, quality and use which satisfies needs. Udeh (1999) Observe entrepreneurship as the willingness and ability of an individual to seek out investment opportunity, establish an enterprise based on this, and run it successfully either for profit - making or social benefit.

Bob Reiss (2000) Stated the concept of entrepreneurship inform of Recognition and pursuit of opportunity without regards to one's current control resources, with confidence and assurance of success, and with the flexibility to challenges topic as necessary and the will to rebound from setback. The general overview of this concept is that entrepreneurship therefore deals with the identification of gaps and business opportunities in one's immediate environment and bringing together the necessary resources in an innovative way to fill these gaps, bearing the risks involved and in the process gaining personal reward (which may or may not be for profit motives)

\section{Historical perspectives of entrepreneurship development}

The words entrepreneurship was coined from a French word entrepredre which means a person who voluntarily heads military expedition. It was first used during the French military history in the seventeenth century. Literally, the word was Translated to mean" betweentaker" or go- between the concept of lassies-fair capitalism propounded by Adams smith which permitted free entry and free exit of the merchants to the market actually helped in the 
development of entrepreneurship. Prior to this period however, different people had been identified to exhibit the future of an entrepreneurship.

Early Age- During this period a good example of an entrepreneur (acting as a go -between) was Marco polo, who attempted to establish a trade route to the Far East. As a go- between he would sign a contract with a venture capitalist to sell his goods, which as a merchant, he undertook both the physical and emotional aspects of risk involved in the venture.

Middle Ages- During this period, the word entrepreneur was used to describe both an actor and a person who managed large production projects but may not necessarily be a risk taker but a manager of a project using the resources provided to him. Entrepreneur was also seen as an architect or a handler of government contract. The middle ages are the period of European history from the fall of the Roman Empire (c,476AD) to the late $15^{\text {th }}$ century.

$17^{\text {th }}$ century-this period witnessed the gradual application of the entrepreneurial concept to business development. This was in connection with profit, according to John law, a notable French businessman who established the Royal Bank. During this Era, Richard Cantillion, an Irishman, first adopted the word entrepreneur to describe a risk bearer when he observed that farmers, merchants, craftsman and others actually bought their goods at a certain known price and sold at an unknown price bearing the risk involved.

$\mathbf{1 8}^{\text {th }}$ century-In the 18 century, entrepreneurship began to assume a greater application to business and the business environment particularly as capital or fund demanders or users. This period conceded with the industrial era. Many inventors such as Thomas Edison, Whitney and others were identified as entrepreneurs. Here the inventors attempted to produce or turn their inventions in to products in commercial qualities but lacked the capital to do so. This created a situation where a capital/ funds providers became separated from the fund or capital demanders. In this century the concept of entrepreneurship was viewed as capital demand and use, the entrepreneur as one who made use of capital for his invention for commercial purpose. Two levels of profit were then recognized. For instance, Jean Baptize was able to separate the profit of entrepreneurship from that of capital. The profit capital went to the fund providers while residual profit or the profit of an entrepreneurship accrued to the entrepreneurs.

$1^{\text {th }}$ Century- During this century the concept of entrepreneurship assumed economic and Managerial perspective, the entrepreneur was seen as someone who combined the factors of production (such as land, labour, capital, information and personal initiatives, skill and training) for profitable rewards.

$20^{\text {th }}$ Century- the concept of entrepreneurship in this era was that of innovation, Schampeter was one of those who introduced the concept of innovation. Innovation means the Creation or introduction of new method, new machine, new process, new materials, new market, new product and new organizational structure. According to Hisrich and Peters (1985), the entrepreneur was viewed as an innovator or individual who develops something that is unique. They point out that the function of the entrepreneurs was to reform or revolutionize pattern of production or the production process

$21^{\text {st }}$ Century - in the $21^{\text {st }}$ century entrepreneur have been further expanded, for instance, Shapro (1975) sees an entrepreneur as someone who exhibits a kind of behaviour which 
includes taking initiatives, organizing and re-organizing social and economic mechanism to turn resources and situations to practical profitable ends, accepting of risk or failure. Vespa (1980) views an entrepreneur from the following perspective (i) the economic perspectives; this concept sees entrepreneur as person who combines resources such as labour, materials and other assets, introduce changes, innovation and new orders for profitable and rewarding ends (ii) the Psychological perspectives; on the other hand this perspective sees an entrepreneur as someone who is being driven by certain force that are mainly internal, personal attributes and traits. (iii) the Business perspectives concept sees entrepreneur as someone who Maximizes profit.

\section{The word entrepreneur}

In 1961, David Maclelland described an entrepreneur as someone that meets the needs of others for personal achievement. Peter Drunker (1964) see entrepreneur as a maximizer of opportunity, wealth and someone who is highly creative. An entrepreneur is anyone who owns a business enterprise for purpose of making profit. They are; Contractors, Producers, Investors, Traders, Industrialists, Manufacturers etc. they can be directly involved in the Management of their business or through any other person. He/she is seen as someone who runs a business at his own financial risk. He/she is a tradesman or craftsman who can produce a product or provide a service primarily by himself or herself.

Thus, an entrepreneur creates employment for people. He can pull (employ) people together from different disciplines (occupational background) to work as a team with view to achieve a common goal which is profit. Motivation is a prime factor for the entrepreneur who is often called pacesetter. In a broader case, owners of trading outfits block making companies, tailoring services, Farmland, information technology companies, electrical/ technical companies, welding outfits, business center, barbing salon, hotels, etc, all these petty businesses that have employees are entrepreneurs irrespective of their educational background, provided they have basic skills for the leadership and success of these enterprises and their target is to make profit.

To make profit is often difficult and slow but entrepreneurs are driven by the need to achieve uncommon things, to accomplish something difficult to master, to manipulate or organize physical objects, human beings or ideas. However, the following factors are very important for the success of an entrepreneur. Educational background, Vision, organization, available funds, environmental condition, availability of infrastructural, legal frame work, information accessibility, cost control and Management, quality of services/ product, discipline and determination.

\section{Qualities of Good entrepreneur}

1. Skills for self business initiation; it is in human nature to always think of something to do, the first step is hardest and encompasses fear, but not necessarily. You must learn how to overcome fear from mind.

2. Self Confidence; true self confidence comes after some efforts have been made and Observation recorded.

3. Perseverance; this is what separates winners from losers in most things of life. Persistence is therefore necessary for fuller maturity of business target. 
4. Leadership. This quality entails the ability to take decisions since no one does business alone, everyone should be directed and made to be focused on the same goals. This is very crucial to success. Success doesn't come until you accomplish something tangible.

5. Problem solving skill; this entails the identification of problems, list the benefits and hindrances of each problem, step by step solutions as well as plan the work and work the plan.

\section{Entrepreneurship: The Nigerian Experience}

Entrepreneurship in Nigeria also suffers some setback due to some reasons beyond the reasonable controls by the owners. Ajagu (2005) presented a critical assessment of some prognosis affecting entrepreneurial development in Nigeria. He argues that the country offers several opportunities for entrepreneurial development. The intending entrepreneurs can take advantage in industries where there are investment opportunities in crude oils, coals, tin, columbite, palm oil, peanuts, cotton, rubber, wood, textiles, cement and other constructional materials, food products, foot wear, chemicals, fertilizers, printing, ceramics and steel. Entrepreneurs also have advantage in the area where there is abundant opportunities to invest in Agricultural production such as in cocoa, peanuts, palm oil, beans, corn, rice, sorghum, millet, maize, cassava, yam, groundnut, cattle, goat, sheep, fish, timber, pigs, etc.

Given the above mentioned analysis of the natural and material resources, Nigeria can be described or viewed as a safe environment for operating entrepreneurship business. This has accounted for the increasing influx of foreigners seeking to establish business in Nigeria. It is no more news Nigeria being the most populous black nation in the world, and has the largest market in African sub-region. He argued that there are some setbacks that entrepreneurs have to contend with in their course of doing business in Nigeria. The work captured a myriad of problems facing the smooth soil of entrepreneurship in Nigeria which have contributed to the sad reality of several entrepreneurs closing shops daily.

\section{Entrepreneurship and job Creation in Nigeria}

Job creation simply means the process of providing employment especially to people who are unemployed. It is also the process of making more paid jobs available. Entrepreneurship is an engine room through which an individual become creative, innovative and self dependent in any society. Entrepreneurs play a significant role in job creation in Nigeria.

Over the years, Nigerian government through public service implements various approaches all with sole aim of creating and providing more job opportunities to the younger generation in order to address the problems of unemployment. Unemployment is the inability of a matured citizen, young, adult, old, individual to acquire employment to carter their basic needs. Unemployment is a serious menace which exists among the people in all developing countries. According to National bureau of statistics, the unemployment rates for Nigeria between the year 2000 and 2016 showed that the number of unemployed persons constituted $31.1 \%$ in $2000 ; 13.6 \%$ in $2001 ; 12.6 \%$ in $2002 ; 14.8 \%$ in $2003 ; 13.4 \%$ in $2004 ; 11.9 \%$ in $2005 ; 13.7 \%$ in $2006 ; 14.6 \%$ in $2007 ; 14.9 \%$ in $2008 ; 19.7 \%$ in $2009 ; 19.7 \%$ in 2010 and $23.9 \%$ in $2011 ; 10.6 \%$ in $2012 ; 10.0 \%$ in $2013 ; 21.24 \%$ in $2014 ; 14.78 \%$ in $2015 ; 13.3 \%$ in 2016 (source; Nigeria Bureau of Statistic, unemployment report 2016). 
Nigerian government through its poverty alleviation programme initiated different forms of empowerment programmes which resulted in creating employment and policies targeted at reduction/eliminating the menace of poverty, unemployment in the Nigerian communities. Among these programmes established by Nigerian government are;

* National Directorate of Employment (NDE) in 1989

* Youth Empowerment Scheme (YES) in 1999

* National Economic Empowerment and Development Strategy (NEEDS) in 1999

* Graduate Empowerment Scheme (GES) in 2004

* National Open Apprenticeship Scheme (NOAS) in 2009

* Graduate Internship Scheme (GIS) in 2012

* Social Investment Programme (SIP) in 2016

* Conditional Cash Transfer (CCT) in 2016 etc.

* Future Assured (2017)

* APPEALS (2019).

It was part of the cardinal electioneering campaign promises by the present administration. The programmes no doubt seeks to alleviate the suffering of Vulnerable Nigerians and to provide the unemployed graduates youths with Job apprenticeship opportunities that will expose them to skill and experiences relevant to the current labour market and enhance their Employability (FGN 2016).

\section{Risk of Business Failure}

Nwachukwu (2005;39-45) presented full factors that are responsible for business failure in our environment. These factors are hoped to help entrepreneurs to identify the danger sign and attempt to prevent business from crashing. The research has shown that the failure rate is highest in small enterprises than in medium or large scale enterprises. Business failure is not new in Nigeria. Although statistics on business failure rate in Nigeria is not very reliable, the failure rate seems to be about 4 in every 10 in retail enterprises. A recent study conducted in four Eastern States - Anambra, Imo, Rivers, and Cross River on the business failure rate gave an alarming picture. Between 1984-1987, 3,875 enterprises had permanently closed their doors. This situation appeared to be worse in Port Harcourt where 5 in every 10 small enterprises in manufacturing or processing had either permanently or temporarily gone out of business. The major factor accounting for this trend is the state of the economy.

\section{Summary of the challenges of entrepreneurs in Nigeria}

The challenges which an entrepreneur encounter during operation can be viewed as unforeseen or unpredictable outcomes surrounding any business venture. These challenges 
are not insurmountable because many of the challenges are discovered at stage that an entrepreneur is supposed to carry out its feasibility studies.

The trend is so ugly that entrepreneurs have continuously cried out that their businesses are folding up due to some reasons.

1. Feasibility Studies; This is what is referred to as business plan, proceed with strategizing on how best to actualize your stated objectives. At the end the strategic plan will contain long term plan of action. The strategic plan must be targeted towards the study of the proposed business. It may be difficult to determine all the information necessary for long term planning especially when the intending entrepreneur is going in to business for which she/he has no knowledge about.

2. Funding; This has been a major challenge for an intending entrepreneur because without adequate funds, all your Vision and plans may come to nothingness. To carry out a tentative and successful feasibility study some amount of funds is required for transportation and information gathering and even to engage a professional when necessary to do so. The entrepreneur is faced with the challenges of securing initial capital to kick start the business.

3. Poor Infrastructure: Entrepreneurship unfortunately in the Nigerian state can hardly boast of the satisfactory delivery of these amenities that are basic to increase the morale of an entrepreneur. This is not unconnected with the lack of priority given to the provision of electricity, water supply, good roads by both past and present administrations in the country.

4. Unstable macro-economic variables: Perhaps another major concern that is very worrisome in Nigerian entrepreneurial sphere is lack of stable macro-economic variables. This has over the years, eroded entrepreneurs confidence in doing business in Nigeria, as they are unable to have stable financial plans and budgets. It has resulted to inefficiency and technology backwardness.

5. Fiscal Policy; Entrepreneurs in Nigeria are saddled with all sort of unimaginable taxes and tariffs that can best be described as a Crisis- Situation. Due to the absences of a unified and gazette tax regime among the three tiers of governments, each of them especially the state and local government tend to enact all forms of obnoxious and draconian tax laws to raise money at the expense of the investing public.

6. Corruption/ Trade Malpractices: Another major malaise militating against entrepreneurship in Nigeria is corruption/trade malpractices. The act of dishonesty and illegal behaviour has eaten deep in to the system. Corruption, according to oxford Dictionary of current English, is dishonesty or illegal behaviour. Section 2 of the corrupt practices and other related offences act 2000 define Corruption to power or position of trust for personal or group benefit (monetary or otherwise). Corruption undermines good government, democracy, human right, security and government's quest to provide basic amenities.

7. Fear of failure; As an entrepreneur, you would always be confronted with the fear of failure until you possibly overcome it when you must have been solidly established.

8. Societal Expectations; As an entrepreneur there will be much more societal expectations from you. The moment it is known that you now run your own business the demands from family, friends, in-laws and indeed all persons tend to increase. 
9. Management; The daily management of the business can either be done by the entrepreneur or entrusted managers, depending on the form of business the entrepreneur chooses. However, the three important managerial skills absolutely necessary to make the enterprise successful are (i) Management of cash flow (ii) Management of people and (iii) Management of personal time.

10. Inadequate knowledge; For Coordinating the business properly.

11. Multiplicity of initiatives ideas; Especially the introduction of ICT Knowledge without any training/seminar from expert which resulting in Duplication of efforts and wastage of resources.

12. Lack of enforcement of Nigeria patent laws discourage entrepreneurs from commercializing of their ideas and invention.

13 Insecurity: There is no guarantee of life and property in Nigerian business environment. It is very difficult to operate successful venture: according Arizona (2009) Nigeria has become a den of kidnapping and resulting in incessant hostage taking, kidnapping unjust harassment.

\section{The Way Forward}

Any entrepreneur practices that emphasizes growth and expansion without due regards to the development of reliable source of funding, an adequate supply of well trained business guru from different business world, infrastructural facilities to accommodate natural and stimulated increase in entrepreneur population and a dynamic economy to absorb graduates from labour market is lying the seeds that will, on germination, create an environment in which all types of crises will flourish. Such is the experience of the Nigerian entrepreneurship in its role toward building a strong nation.

1. The planning, control and management of entrepreneurship should be left to those who are professional, learned people that arguably have training, experience and above all, the interest and commitment necessary to achieve the effective development of the enterprises and attainment of both short-term and long -term business aims and objectives.

2. Placing too much value on the possession of certificates rather than on the acquisition of requisite knowledge and skills should be discouraged. The government must also ensure proper implementation of good policy that would improve the quality and supported entrepreneur to boost the nation economy through skill acquisition programme.

3. The government should also ensure that its reduce the interest rate regime or harmonize the various taxes charged especially those from three tiers of government for the purpose of encouraging infant industry to operate actively.

4. The challenges before the nation's economic managers are to put the economy on the path of competitiveness and strengthen it to participate effectively and compete favorably with in the global system. The government should update the infrastructure, improve access to Information communication Technology. This is an obvious tool for any contemporary Business organization, and it has strong connection to enhancing market productivity. 
5. Corruption and inefficient monopolies must quickly deals with and give away through proper monitoring and accurate implementation of policy. In the other hand government should put extra-extra measures to empowered entrepreneurs who are in needs to boost their business. Firms should also develop their HR capabilities that closely match the particular market in which they want to do the business.

6. On its effort to create a viable economy, the present administration introduced a new programme which is called future assured, led by Her, Excellency Hjiya Aisha Buhari, aimed at promoting and empowering entrepreneurs with loan.

7. Entrepreneurs should be trained and retrained with current ideas through short term medium term and long term programmes in order that they can update and upgrade themselves in the current entrepreneurship practices toward building strong nation.

8. All stakeholders must encourage the proposed introduction of entrepreneurship study as compulsory course to all undergraduate student of all tertiary institution in Nigeria, also government should put machinery in place to provide an enabling environment for entrepreneurship practices.

\section{Theoretical Framework}

This study is anchored on the innovation theory of entrepreneurship which was first advocated by Joseph Schumpeter in 1934. A dynamic theory of entrepreneurship was first advocated by Schumpeter (1949) who considered entrepreneurship as the catalyst that disrupts the stationary circular flow of the economy and thereby initiates and sustains the process of development. Schumpeter introduced the concept of innovation as key factor in entrepreneurship in addition to assuming risks and organizing factors of production. Schumpeter (1991) notes that creativity as well as innovation is the key factor in any entrepreneur s effectiveness and efficiency. However, Schumpeter viewed innovation along with knowledge as the main catalysts of successful entrepreneurship. He believed that creativity is necessary if an entrepreneur is determining break even in a stiff competitive market. Schumpeter sees entrepreneurship as - a creative activity. An innovator who brings new products or services into economy is given the status of an entrepreneur. He regards innovation as a tool of an entrepreneur. The entrepreneur is also viewed as the engine of growth' which sees the opportunity for introducing new products, new markets, new sources of supply, new forms of industrial organization or for the development of newly discovered resources. Therefore, this theory is relevant to the study because it enables the entrepreneurs, SMEs to identify their potentials in a systematic way and improve their ability to meet there global counterpart.

\section{Empirical review}

Various studies have revealed that good entreprenuership practice has significant effect on building a strong economy of the nation. Abiola (2014) carried out a study on Small and medium scale enterprises in Nigeria: the problems and prospects, the objective of the study was to examine the role of small and medium scale enterprises in Nigeria in relation to these challenges which effect SMES from developing capacity to realizing it full potentials as well as the prospect for improvement and development of employment generation, economic growth and national development. The study employed a descriptive research such that 
structured questionnaire was administered to the sample drawn from the population of the study. The data collected were analyzed using chi-square $\left(\mathrm{x}^{2}\right)$. it was revealed that Small and medium scale enterprise play vital role in the socio-economic well being of the citizens, if properly and carefully managed. From the research finding the study therefore conclude that invigorating small and medium scale enterprises (SMES) with strengthened commitment to economic reforms would offer a turning point in facilitating the recovery of Nigeria economy and national development.

Ayozie (2013) conducted a study on implication of small and medium scale enterprise (SMES) on socio-economic development in Nigeria, the aim was to determine the effect of small and medium scale enterprise (SMES) on Nigerian economy. The study employed a survey research design of which structured questionnaire was administered to the sample drawn from the population of the study. The data collected were analyzed with chi-square $\left(\mathrm{x}^{2}\right)$ and it was found that small and medium scale enterprises (SMES) assist in promoting the growth of the country, hence all the level of government at different time s has policies which promote the growth and sustenance of SMES and therefore concluded that small scale industry orientation is part of the Nigerian history. Evidence abound in the communities of what success our great grand parent, made their respective trading concerned, yam barns, cottage, industries and the like.

Kriss (2012) conducted a study on impact of small and medium scale enterprise on the economy. The study was aimed at determine the impact of small and medium scale enterprise on the economy, the study employed a survey research design of which questionnaire was administered to the sample drawn from the population of the study, the data collected were analyzed using chi- square $\left(\mathrm{x}^{2}\right)$ it was found that the contribution of small scale enterprise to the economy cannot be over emphasized because it provides job/employment for the people and enhance their standard of living. Therefore the study concludes that the government at all levels should provide succor to the small scale enterprises by way of advancing loan, sensitization programmes to encourage enterprises.

Asogwa, Ogochukwu, and Dr. Stanly, Arinze (2017) conducted a study on impact of entrepreneurship development on economic growth of Enugu state; the study revealed that entrepreneurial activities create job opportunities which subsequently enhance the standard of living of the people of Enugu state and therefore concludes that the role of entrepreneurial activities on economic development cannot be over emphasized because it enhances the socio-economic well-being of the people. Adejumo (2001), Ariyo (2005), Agboli and Ukegbu (2006), Abimbola and Agboola (2011) Thaddeus (2012), Oyelola et al. (2013), Salami (2013) revealed that entrepreneurship development is the key to poverty eradication, employment creation and rapid growth of economic development, various government in Nigeria have over the past three decades evolved policies and programmes aimed at developing entrepreneurship through the development of small and medium scale enterprises (SMES).

A conceptual framework for this study is drawn from entrepreneurship development theory. Entrepreneurship is the process of initiating and managing business organisation to accomplish societal objectives. It also willingness and ability of an individual, group of individual or government entity to seek out investment opportunities, establish and run an enterprise successful. In the other hand An entrepreneur is an individual, group of individual or government entity who undertake the responsibility of making innovations in the economy (developing a new source of supply of raw material, new method of production or 
distribution, introducing new goods/service and opening a new market) or carries out a new organisation or industry. The purpose of entrepreneurship is to diversify economic activities and also create opportunities within the economy. Therefore this study would make significant contribution to the existing body of knowledge in the study of entrepreneurship using conceptual data.

\section{Methodology}

This study is investigative in nature, consequently the analytical methodology adopted was conceptual in nature. Intensive library work was carried out to explicate the conceptual issues. The nature of the study did not however, necessitate the use any sophisticated mathematical instrument or statistical analysis. Hence the study relied heavily on secondary data publish and drive from books, journals, E-libraries, student dissertation, online data base, internet using goggle.com, CBN report, NDE, Federal office of statistic (FOS) and other related document.

\section{Conclusion}

Entrepreneurs are the bedrock of every society. Their activities bring about the growth and development of economy. We, therefore, never look down on any individual that is able to think out an idea, implement it and solve a problem for humanity no matter how small the solution they provide. This study sought to determine the entrepreneur's perception and their quality of operation in Nigerian Business environment. There is no doubt that globalization is the core of the world new economic order. With this, the world has become a global village, resulting in the free movement of goods and services across national boundaries and no government can isolate its people, citizens against the global free enterprise system.

However, the research showed that no country can succeed where there is no effective operation of entrepreneurship practices, the research noted that Nigerian Government has in the past been formulating certain policies and planned other programmes to create employment for unemployed Nigerians. The various job creating programme and the brilliant success of the entrepreneurship practices have been adequately examined. Despite the enormous impact of entrepreneurship in Nigeria the study noted that currently the number of people engage in this business is below expected. The reason may not be unconnected with the spilled over problems of 1970s and 1980s in the economy. The study commended the government initiatives for provision of long term, medium term loan and short term loans to the prospective $s$ entrepreneurs who are capable of improving their productivity toward building a strong nation.

\section{Recommendations}

The following represent key recommendations for making entrepreneurship in Nigeria virile and vibrant through the creation of an enabling environment for optimum performance. The study therefore recommends that entrepreneurs' practices in Nigeria should not relent in their effort on job creation, innovation and poverty reduction toward building strong nation. The government should provide the enable environment for private sector led investment for economic development, by providing adequate infrastructural facilities e.g water, electricity, roads network, communication etc. 
The government through the central bank of Nigeria should establish the much-waited national credit scheme of entrepreneurs which should guarantee at least $80 \%$ of loans needed by entrepreneurs, small and medium enterprises. The entrepreneurs should inculcate the habit of training and developing their management and staff in order to build capacity for meeting the challenges of time and embrace the advantage of development, information and telecommunication technology and other Technological area. In addition, government should reduce the tax rate for entrepreneurs to zero percent $(0 \%)$ throughout their life time of operations. Consequently, the policy makers should endeavour to understand the nature, problems and needs of SMEs/ entrepreneurs before enunciating policies for the sub-sector. In this regard, policy makers should consult with relevant stake holders before enacting such policies that affect them. Above all, the government should have the political will to effectively and efficiently implement the above recommended measures in order to achieve the desired result. 


\section{REFERENCE}

Abiola, R (2014), Small and Medium scale Enterprises in Nigeria: the Problems and Prospects. Journal of Management Science vol. 4 (3). pp. 242-253

Abimbola, O.H \& Agboola,G.M (2011), Environmental Factors and Entrepreneurship Development in Nigeria, Journal of Sustainable Development in Africa. 13(4) 166176. Retrieved from wwwjsd- Africa.com

Adejumo, Linus, Egwu (2014), Entrepreneurship Development in Nigeria, A review Journal of Business and management. P.1

Agboli, M \& Ukaegbu, C.C (2006), Business Environment and Entrepreneurial activities in Nigeria: Implications for industrial Development. Journal of modern African studies 44 (1) 1-30

Ajagu, A.N (2005), the entrepreneurship in Nigeria; Lagos Betcy media.

Ariyo, D. (2005), Small firm are the backbone of Nigerian Economy Retrieved from http://www.Africaeconomicanalysis.org

Arizona, L.C. (2009),” Nigeria fast Becoming kidnappers den?” Business Day, Wednesday 21 December.

Ayozie, D.O. (2011), The role of Small scale Industry in National Development in Nigeria, Universal journal of Management and social science p.33-37

Ayozie, H. (2013), Implication of Small and Medium scal enterprises (SMES) on Socioeconomic Development in Nigeria. Journal of Business studies vol.3 (2) pp. 207214

Broom.,H.N. \& Longenecker J.G (1975) Small Business Management, Cincinnati; Western Publishing.

CBN (2018) Central Bank of Nigeria.

Chea, P. (2009). Relationship between Entrepreneurs Value, Firm Financing, Market

Practices \& Growth Performance of Small-Medium Enterprises in Cambodia. $P h D$ Thesis, University of Utara, Malaysia, Sintok, Kedah, Malaysia.

Editorial, Beyond F.G 's N 5,000 Stipend 2017 January 25 Blue print, p.11

Erinne, C.I. (2004), Government policies and Entrepreneurship Development in Nigeria: p.g 4-5

Federal Republic of Nigeria (FRN), First National Development Plan, 1962- 1968.

Federal Republic of Nigeria (FRN), Second National Development Plan, 1970- 1974.

Federal Republic of Nigeria (FRN), Third National Development Plan, 1975- 1979. 
Federal Republic of Nigeria (FRN), Fourth National Development Plan, 1980- 1985.

Federal Republic of Nigeria (1998), National Policy of Education, ( $3^{\text {rd }}$ edition)

Forje, L.C. (2010), Recreating government entrepreneurship and Proverbs in public administration. Journal of public administration and Policy Research. Vol.2(2),028038. Available online at www.academicjournals.org/jppr-

Guest, D.E. (2011). Human Resources Management and performance; Still Searching for some Answers. Human Resources Management Journal, 21(1),3-13

Idan, Linus, Egwu (2014), Entrepreneurship Development in Nigeria A review Journal of Business and Management p.1

Imeokparia, P. \& Ediagbonya, K (2014). Small and Medium Scale Enterprises (SMEs): A Catalyst in Promoting Economic Development in Nigeria. Journal of Education and Practice, 5 (33), 92-94.

Jatau, M.D. (2010). Toward enhance Effectiveness in an Organization. Publish in Nigeria by KOTZMATZ MEDIA KONZULTS LTD.

Kalajaye, P.O. (2014) The rise of Casual work in Nigeria; Who loss Benefits African Research Review 8(1)158-176)

Kriss, E. (2012)Impact of Small and Medium scale enterprises on economy, Ebsu. Journal of business Education vol. 2(2).

Maina, S. (2014), The role of entrepreneurship education on Job Creation among youths in Nigeria. International Letters of Social and Humanistic Science 4,(2014) 87-96.

Mbah, S.A. Agu. O.C (2013). The effectiveness of government Employment Policies in Nigeria. IOSR Journal of Humanities And Social Science (IOSR-JHS5), Volume 12 Issue 3, PP65.71

NERC and the Pitfalls of Mini- grid regulation (2017), January 25 Blueprint, p.3

Nigerian Bureau of statistic, Unemployment Report Q2 2016

NITDA 2012; Key Informant Interviews, Nigerian Academy of Management Journal. Vol 8, NO,1 June 2014, Ajagu A.N. Entrepreneurship in Nigeria

Nwachukwu, C.C (2005). The Practical of entrepreneurship in Nigeria Onisha; African First Publisher Limited.

Olorunmolu, J.O (2010), Journal of Management Science and Technology education $\quad 4(1)$ $110-115$

Oyelola,O.T. Ajiboshin, I.O Raimi, L. Rasheem,S \& Igwe, C.N (2013), Entrepreneurship for Sustainable Economic growth in Nigeria. Journal of sustainable Development studies 2(2) 197-215, Retrieved from www.worldsustanable.org 
Salami, C.C.E (2013), Youth Unemployment in Nigeria: A time for creative intervention, International Journal of Business and marketing Management. 1(2), 18-26 Retrieved from www.resjounal.org.

Schumpeter J. A.(1934). The Theory of Economic Development, translated by Opie R. Harvard University Press, Cambridge,MA., pp 42-46, 78-89

Tabiu A. \& Nura A.A (2014), Nigerian Academy of Management of Journal Vol, 8 p. 45-52.

Thaddeus, E (2012), Perspectives: Entrepreneurship Development and growth of enterprises in Nigeria, Entrepreneurial practices Review 2 (2) 31-35

www.cenbank.org/out/publication/communique/rsd/2009/non technical \% 20 report. Pdf (accessed on 11/12/2013). 